\title{
A Research of the Need Analysis of the English Majors of Baoding University
}

\author{
Liming Zhang ${ }^{1}$, Jie Han', Huifang Wang² \\ ${ }^{1}$ College of Foreign Language Education and International Business, Baoding University, Baoding, China \\ ${ }^{2}$ North Nuclear Fuel Co. LTD., Datong, China \\ Email: zhangdawn@126.com
}

How to cite this paper: Zhang, L. M., Han, J. \& Wang, H. F. (2020). A Research of the Need Analysis of the English Majors of Baoding University. Creative Education, 11, 2375-2383. https://doi.org/10.4236/ce.2020.1111174

Received: October 26, 2020

Accepted: November 22, 2020

Published: November 25, 2020

Copyright (c) 2020 by author(s) and Scientific Research Publishing Inc. This work is licensed under the Creative Commons Attribution International License (CC BY 4.0).

http://creativecommons.org/licenses/by/4.0/

\begin{abstract}
The study makes a need analysis of 70 English majors based on Baoding University. The focus of the study aims to find out the subjects' actual learning needs and their attitude towards the current curriculum. Results of the study mainly show the following aspects, i.e. the majority of the students' are basically instrumentally motivated, therefore they have a preference for the career-development focused courses. They also have a high evaluation of the current English curriculum and believe it can basically satisfy students' learning needs, however, there are still some modifications that should be made. The current study provides some references for the curriculum design of Baoding University.
\end{abstract}

\section{Keywords}

Needs Analysis, Curriculum Development, English Majors

\section{Introduction}

In this new era of globalization and world unification, it is more and more necessary for English major students to be equipped with not only proficient English language skills but also various other capacities needed to meet challenges in the current world. Naturally the academic quality of the students is mainly determined by the curriculum under which they are trained. What are the individual needs of the present day English major students? What is the evaluation of the present curriculum by English majors in Baoding University? With these questions in mind, the author of this paper made a case study of the individual need analysis of the college students from Baoding University.

The present Curriculum for English Majors of Baoding University, like those of other Chinese universities, proposes three categories of qualifications 
for the English majors: language skills, language knowledge and other English-related specialities. It also points out that the purpose of training English majors is to serve the development of local education and economy. To realize the above-mentioned targets, it designs three kinds of courses: courses aiming at training language skills such as Listening, Speaking, Reading and Writing, courses aiming at basic major knowledge such as Linguistics, Literature, Translation, and others providing possibilities for career development. The curriculum sets two possible visions for the students' career development, i.e. to be a middle school teacher or an international business manager, for the first possiblility, it provides courses such as Skills of Middle School Teaching, Applied linguistics and so on, while for the second possibility, it provides courses such as Commercial Reading, Basic Knowledge of International Trade, etc. Only by making a need analysis of these courses can we lessen the impact of blindness and casualness in the field of foreign language teaching (Chen 2009). This paper will start from the students' need analysis and explore some possible problems existing in the curriculum. Need Analysis will be used as a tool to comprehend students' attitudes towards the current English majors' curriculum.

Both quantitative and qualitative researches are used in the study to investigate and analyze the individual demands of English majors of Baoding University, which mainly include students' attitude to the teaching content and their objectives for learning English. The research also aims to find out evaluations of the students on the current curriculum, etc. The author of the paper hopes the results of the study could enable the school administrators and teachers to understand the new features of different kinds of students' needs, which will facilitate English language teaching and improve the English curriculum design and development.

\section{Literature Review}

Need analysis is a method widely used in foreign language study to determine the learners' need by using such means as introspection, interview, observation and questionnaire. The result of need analysis usually serves as a basis for curriculum designing. An analogy could be made about the importance of need analysis: in the field of foreign language teaching, need analysis can be compared to the diagnosis made by a doctor before his prescription for a patient (Long 2005). Need analysis usually makes it more scientific to design a language curriculum design and conduct classroom teaching. And all in all, need analysis plays an indispensable role in the foreign language teaching (Chen 2009).

Need analysis was oringally applied in the field of English for Special Purpose (ESP) study. The term itself firstly appeared in the Indian literature in 1920s. It was proposed by Michael West (Howatt 1984: p. 245) when he found that the senior English learners' needs were not specified precisely and learners were not in the state of TENOR (Teaching English for Obvious Reason). After that, the theories about need analysis hardly appeared in the related literature until 1970s. At that time the Council of Europe worked hard to advocate the application of 
need analysis in the field of English for Special Purpose. Gradually, with the deepening of the corresponding study, scholars also turned their eyes into need analysis on learners of English for General Purposes.

Need analysis is now widely used by scholars in foreign language study in order to determine the needs of language learners and guarantee the effectiveness of language teaching as well. Due to its popularity and constant contributions from scholars from different parts of the world, a mature, completed system has established presently. There are four models of foreign language need analysis, marking different stages of its development, i.e. Munby's Target Situation Analysis (1988), Allwright's Present Situation Analysis (1982), Hutchinson and Waters model (1987), Dudley-Evans and St Tohn's model (1998).

Munby's Target Situation Analysis aims at providing a series of specific steps named Communication Needs Processor, the target of which is to discover the needs of students' future career or learning situations. The Communication Needs Processor is a partial, initial and terminative need analyzer from which the specific tasks and activities of the target needs could be recognized. However, its drawbacks, such as its over complexity, and much time-consumption and excessive student-centeredness also makes it difficult to be applied to large scale need analysis of foreign language learners who belong to different groups, therefore it usually fails to provide the procedures of language teaching syllabus descended from learners' information (Richards 1994).

Allwright's Present Situation Analysis (1982) is an analyzing procedure that focuses on exploring learners' current knowledge and their possible incompetence in target situations, and based on the result, it aims to provide corresponding purposeful language teaching in classrooms. In nature it is a process oriented analysis, however, it also includes target situation analysis, which makes it a supplement and perfection of Munby's Target Situation Analysis. However, it is not without drawbacks, that is, it ignores the individual cultural backgrounds of the learners as a learning subject (Chen 2009). Hutchinson and Waters model (1987) consists of the framework of target situation analysis and the framework of learning need analysis. While the former analysis emphasizes the application of language, the latter focuses more on the language learning. Although it brings both the analysis of the target need and learning process need into consideration, it weakens the ability to recognize students' lacks to some extent. Dudley-Evans and St John's model (1998) begins with treating students as individuals, language learners and language users, and then conducts both language knowledge and skill learning analysis of seven special groups randomly selected from a large scale learners, finally it also brings the relevant information about target situation of language learning and language learning environment into consideration. By doing these, this model successfully evades the randomness of course design and receives high praise from the field of foreign language learning. As the latest and the most perfect idea in the realm of foreign language needs analysis so far, it has been used widely in the study of such kinds of study worldwide (Chen 2009). 
In this paper, the design of the questionnaire is based on Dudley-Evans\& St John's model. The reasons why the author of this paper adopts Dudley-Evans and St John's needs analysis model can be stated as follows.

First of all, literature shows most of the English language curriculum design adopts Munby's Target Situation Analysis or Hutchingson and Water's model to analyze learners' needs for language learning, which indicates if not being a perfect model, it must be a most effective one. Secondly, Dudley-Evans and St John's needs analysis model is seldom applied to attest the effectiveness of college English language curriculum designing. In this respect, the author of this paper aims to contribute some original ideas to the development of the theory. Lastly, Dudley-Evans and St John's needs analysis (PSA) model consists of Target objective Situation Analysis (TSA), Present Situation Analysis subjective and needs, target needs and learning needs. Though the target of this research is about the individual needs analysis of the English learner, it is apparent that Dudley-Evans and St John's needs analysis model can provide comprehensive information about all different kinds of needs, which is of course more enlightening and beneficial for the current study.

\section{Methodology}

The objective of this study is to conduct an investigation on English majors' individual demands based on the need analysis and English majors of Baoding University. It aims at finding out the individual demands of English majors and providing a reference for the curriculum design and improvement.

1) What are students' demands for English majors' curriculum?

2) What are students' attitudes towards the current curriculum?

The research subjects include 70 English majors from Baoding University. Among those who participate the questionnaire survey, $40 \%$ are freshmen, 20\% sophomores and $40 \%$ junior students. Females students take a proportion of $70 \%$ and male $30 \%$. The demographic features of the subjects show in Table 1. All the subjects are selected randomly from freshmen to junior students in English Department of Baoding University. 15 subjects are selected randomly from those answering questionnaires.

The quantitative approach and qualitative approach are both applied in this study. For the quantitative research, an adapted questionnaire is adopted as an instrument to gather the information of English majors' actual needs of the current study. For the qualitative approach, interviews are adopted to gather more concrete information for the research.

The main content of the questionnaire is based on Dudley Evans and St. John's needs analysis model and adopted some items from Wang (2010)'s needs

Table 1. Demographic features of the subjects.

\begin{tabular}{ccccc}
\hline Freshmen & Sophomore & Junior students & Male students & Female students \\
\hline $40(40 \%)$ & $20(20 \%)$ & $40(40 \%)$ & $30(30 \%)$ & $70(70 \%)$ \\
\hline
\end{tabular}


analysis for ESP courses. The questionnaire aims to finding out English majors needs on current study and their satisfaction to the current curriculum. The questionnaire is made up 17 questions, the first 9 are multiple choices and the last 8 are to be answered by Likert scales. Both parts are designed to figure out the subject's individual needs for studying the English language.

The formal investigation was carried out in January, 2015 and 100 copies of questionnaire were given out. In order to make sure that the students' answer are authentic and reliable; students were told that their answers for this questionnaire could be kept secret and there is no influence between their answers and their final graduation.

The interview is another significant method which is designed to gather information about the subjects' evaluation of the current curriculum. After the questionnaire survey, 15 participants were invited to have an interview serving as a complement and confirmation to the results of questionnaire. Four interview questions are concerned as follows: 1) What kind of English skills do you want to improve and why? 2) What do you think is the most disable class activity and why? 3) What do you think is the most proper course arrangement and why? 4) Do you like the current course arrangement and why? The interviews are carried out in Chinese so that participants can express their own opinions clearly. During the interview the atmosphere was friendly and casual, so the information gathered during the interview can reflect the participants' real thoughts. And the answers of the students' interview were recorded.

The information of students' needs and students' attitude is collected from the questionnaires and the transcriptions of interviewees' answers. After the collection of the data, the program of Statistical Package for Social Science 17.0 (SPSS) and Microsoft Excel 2014 are employed to analyze the data collected from the questionnaires. The answers of the multiple choices are presented as frequency and percentage calculated by Microsoft Excel 2014, and each Likert scale item in the second part of the questionnaire is presented as mean calculated by SPSS 17.0 to demonstrate participants' attitude towards those items. A specific report of the research results and analysis will be showed in the next chapter.

\section{Results and Discussion}

In this part, the author of the paper presents and analyzes the results of the questionnaires and interview in turn. The results of the following aspects related questions will be presented, i.e. questions concerning students' learning objectives, students' favorite type of English majors' courses and their evaluation of courses. These kinds of information are selected in order to answer the research questions and provide a reference for the English Teaching.

The purpose of question 1 is to investigate students' personal objectives of their English Language learning. Table 2 shows the results of question 1.

From Table 2, 90\% students thought it is still necessary to improve their English level for job requirement or the passing the TEM8. However, 10\% 
Table 2. Data of students' choices about their objectives.

\begin{tabular}{|c|c|c|}
\hline \multicolumn{3}{|c|}{$\begin{array}{l}\text { Question 1: Do you think it is necessary to improve the English knowledge and } \\
\text { application ability when you passed the Test for English Majors-4 (TEM4)? }\end{array}$} \\
\hline Choices & Frequency & Percentage \\
\hline $\begin{array}{l}\text { It's necessary because the present English level } \\
\text { can't meet the future job's requirement. }\end{array}$ & 36 & $51 \%$ \\
\hline It's necessary because of the requirement of TEM8. & 27 & $39 \%$ \\
\hline It's unnecessary because there is no interest in it. & 5 & $7 \%$ \\
\hline It's unnecessary because there is no use in real life. & 2 & $3 \%$ \\
\hline
\end{tabular}

students considered there is no necessity to continue their English study. The results show that most students are not so satisfied with their present English level and want to have a further learning. The truth behind the fact is that most students are always under the pressure of test and future job. Instead, it also shows that most students have a strong desire to improve their English competence for whatever reason. The result also indicates that the teaching of English majors should pay more attention to their needs of future job since $46 \%$ English majors thought they want to learn more to meet their future job's requirement.

The following question is designed to find out students' different needs of different types courses and Table 3 shows the result.

Table 3 shows students' interest in different types of courses. Language-skilled focused courses include the courses of Listening, Speaking, Reading, and Writing. Major knowledge focused courses include the courses of Translation, Linguistics, English Literature and so on. Career-development focused courses include those which aim to equip the students with some basic knowledge for their possible future career development, and the two possible career developments include middle school English teacher and international business managers. From the table, $49 \%$ students chose career-development focused as their favorite type of courses, what comes next is language-skill focused courses and last is major-knowledge focused. The result indicates most of the students' learning of English is career development motivated. Their second preference of language-skill focused courses shows they believe good language skills might help them finding good jobs.

Question 5 is designed to observe whether the current English course learning can satisfy students' needs. The results are presented in Table 4.

From Table 4, the results of question 5 show that $37 \%$ students considered that the present courses learning can basically satisfy their needs on the development of English skills. $42 \%$ of students think they can generally master the skills they need by means of the current English course learning. Among 70 Participants, $10 \%$ of students can master skills they need completely. However, still $3 \%$ of students consider they cannot master the skills completely through the English courses learning.

The following question is designed to investigate students' attitude towards the current course arrangement. The results present in Table 5. 
Table 3. Data of students' choices about their favorite courses.

\begin{tabular}{ccc}
\hline Question 2: What's your favorite type of English courses? & \\
\hline Choices & Frequency & Percentage \\
\hline Language-skill focused & 28 & $40 \%$ \\
Major-knowledge focused & 8 & $11 \%$ \\
Career-development focused & 34 & $49 \%$ \\
\hline
\end{tabular}

Table 4. Data of students' satisfaction to their achievement in English.

\begin{tabular}{ccc}
\hline Question 5: Can you master the skills you need through the present learning? \\
\hline Choices & Frequency & Percentage \\
\hline Completely master the skills & 7 & $10 \%$ \\
Basically master the skills & 26 & $37 \%$ \\
Generally master the skills & 29 & $42 \%$ \\
Barely master the skills & 6 & $8 \%$ \\
Totally incapable of master the skills & 2 & $3 \%$
\end{tabular}

Table 5. Data of students' satisfaction to the course arrangement.

\begin{tabular}{ccc}
\hline \multicolumn{2}{c}{ Question 9: Are you satisfied with the present course arrangement? } \\
\hline Choices & Frequency & Percentage \\
\hline Quite satisfied & 5 & $7 \%$ \\
Very satisfied & 35 & $50 \%$ \\
General & 27 & $39 \%$ \\
Dissatisfied & 2 & $3 \%$ \\
Dissatisfied extremely & 1 & $1 \%$ \\
\hline
\end{tabular}

Table 5 shows the results of students' attitudes towards the present course arrangement. $40 \%$ of participants choose to be satisfied and $39 \%$ give their neutral attitudes, still there are $4 \%$ of them were quite satisfied with the current course arrangement. From the analysis of the results, the overall satisfaction degree is quite high.

During the interviews, students were asked about the question: "Do you like the current course arrangement and why?" students' answers to this question are summarized as follows:

Of all the interviewees, students said they like the current course arrangement. The reasons can be stated as follows. Firstly, it is known that the whole college English courses of our university are divided into two parts: Basic English courses and advanced/elective courses. They said the basic English is necessary for them since it lays a solid foundation for the future English learning. And the basic English course provides a systematic English learning, which is beneficial for students who want to participate the examinations such as TEM4 or TEM8. Secondly, the diversified elective English courses have done a great work on sa- 
tisfying the diversified needs of different students. Students said that the elective courses arouse their interests in English, get more extra curriculum knowledge about the English culture, have a better understanding of English language, and these courses help them make up their deficiency in English effectively especially heir listening and speaking ability.

Two interviewees said the current course arrangement needs to be improved for several reasons as follows. First of all, the options of courses are not enough for students. As certain students are aware of the application of English skills in the future work, they demand more advanced courses on the specialized English. Secondly, the time or sequence of the course should be modified, Such as the sequence of Mandarin Course and English Teaching Techniques Course. They thought these two courses should be arranged in the first or the second academic year, since there are so many advanced courses in the last two academic years. And those two courses also should be learned in advance.

\section{Conclusion}

Major findings are concerned with the exploration of the two research questions. The students' needs for English majors' courses mainly involve the following aspects including the course types, learning styles of relevant courses, etc. Firstly, most students are instrumentally motivated to enhance their English abilities to expand the scope of knowledge. Other students are intrinsically motivated to learn English for future work or exams. And most of students consider career development focused English courses as a necessity to develop practical language competence to meet their future needs. Secondly, the language skills courses are the most popular advanced courses among students due to their practicality and utility in students' daily lives and their future work.

As a whole, students are satisfied with the current English curriculum. It can be concluded from the following aspects. Firstly, as for students' attitudes to their achievements in courses learning, they consider that the present course learning can generally satisfy their needs for developing their English skills as a whole. Secondly, nearly half of the students are satisfied with the course arrangements.

Like any other researches, this research is of course without any problems or limitations. Firstly, according to Long, a complete needs analysis should gather information via various methods and from various sources (Long 2005). The purpose of this thesis is to make a survey on the individual demands of English majors of BDU and give some suggestions to the curriculum design and development, however, the current research doesn't make a follow-up study to check whether the students can meet their job requirement after graduation. Secondly, needs analysis should be an ongoing process throughout a course. A complete needs analysis should include pre-course needs analysis, mid-course analysis and post-course analysis for students' needs changes during the course proceeding. This research only focuses on mid-course needs analysis. It provides a partial 
view of students' learning needs. A whole needs analysis can be carried out containing pre-course needs analysis, mid-course needs analysis and post-course needs analysis.

\section{Acknowledgements}

This paper is under the project of "Reform of English Major Teaching under the Perspective of Need Analysis Theory (Project No. 2014010216)" sponsored by Baoding University. I am deeply indebted to all the team members, who offered invaluable advice and comments.

\section{Conflicts of Interest}

The authors declare no conflicts of interest regarding the publication of this paper.

\section{References}

Allwright, R. (1982). Perceiving and Pursuing Learner's Needs. In M. Geddes, \& G. Sturtridge (Eds.), Individualization. Oxford: Modern English Publications.

Chen, B. B. (2009). A Critical Review of Needs Analysis Studies in Abroad. Foreign Language Teaching and Research, 2, 125-130.

Dudley-Evans, T., \& St John, M. J. (1998). Developments in English for Specific Purposes: A Multi-Disciplinary Approach (pp. 5-7, 15-17,121-132). Cambridge: CUP.

Howatt, A. (1984). A History of English Language Teaching. Oxford: OUP.

Hutchinson, T. \& Waters, A. (1987). English for Specific Purpose: A Learning Centered Approach. Cambridge: CUP.

Long, M. H. (2005). Second Language Needs Analysis. Cambridge: CUP. https://doi.org/10.1017/CBO9780511667299

Munby, J. (1988). Communicative Syllabus Design. Cambridge: CUP.

Wang, F. M. (2010). ESP Curriculum Design: A Learner-Centered Perspective. Shanghai: Shanghai International Studies University. 